\title{
DANA PIHAK KETIGA PADA PERBANKAN SYARIAH DI INDONESIA
}

\author{
Budi Gautama Siregar ${ }^{*}$ \\ ${ }^{a}$ Fakultas Ekonomi dan Bisnis Islam IAIN Padangsidimpuan \\ $\mathrm{a}^{*}$ email : budigautama@iain-padangsidimpuan.ac.id
}

\begin{abstract}
This research aims to analyze the effect of the equivalent rate, inflation, and liquidity on third-party funds in Islamic banking in Indonesia for the 2015-2019 period. The research population is Islamic banking financial statements with a monthly period from 2015-2019. With the saturated sampling technique, the number of samples is 60 months. The data collection technique used is a documentation study, namely the financial statements of Islamic banking in Indonesia published by the Financial Services Authority and Bank Indonesia. Data processing is done by multiple regression analysis with the help of the SPSS application. Research findings that the equivalent rate affects third party funds, inflation does not affect third party funds and liquidity affects third party funds
\end{abstract}

Keywords: Equivalent Rate, Inflation, Liquidity, Third-Party Funds

Abstrak

Penelitian ini bertujuan untuk menganalisis pengaruh equivalent rate, inflasi dan likuiditas terhadap dana pihak ketiga pada perbankan syariah di Indonesia periode 2015-2019. Populasi penelitian adalah laporan keuangan perbankan syariah dengan periode bulanan dari tahun 2015-2019. Dengan teknik sampling jenuh ditentukan jumlah sampel sebanyak 60 bulan. Teknik pengumpulan data yang digunakan adalah studi dokumentasi yaitu laporan keuangan perbankan syariah di Indonesia yang dipublikasikan oleh Otoritas Jasa Keuangan dan Bank Indonesia. Pengolahan data dilakukan dengan analisis regresi berganda dengan bantuan aplikasi SPSS. Temuan penelitian yaitu equivalent rate berpengaruh terhadap dana pihak ketiga, inflasi tidak berpengaruh terhadap dana pihak ketiga dan Likuiditas berpengaruh terhadap dana pihak ketiga

Kata Kunci: Equivalent Rate, Inflasi, Likuiditas, Dana Pihak Ketiga

\section{PENDAHULUAN}

Perbankan merupakan salah satu lembaga yang membantu mendongkrak pertumbuhan ekonomi bangsa. Keberadaan perbankan baik dengan konvensional maupun syariah terus mengalami perkembangan yang mengakibatkan lalu lintas uang di tengah-tengah masyarakat dapat berjalan dengan baik. Setelah terjadinya krisis moneter di Indonesia di tahun 1998, bank syariah menjadi alternatif dalam menumbuhkan perekenomian bangsa (Belinda, 2017, p. 15). Dalam perjalanannya bank syariah yang merupakan bagian dari lembaga keuangan mempunyai tugas utama sebagai perantara dalam hal penyaluran dana dengan berprinsip syariah.

Bank syariah yang sumber dananya berasal dari masyarakat dapat berupa giro, tabungan, deposito berjangka yang disebut dengan dana pihak ketiga. Ketertarikan masyarakat akan produk dan jasa yang ditawarkan oleh bank syariah, mengakibat pentingnya peran dana pihak ketiga terebut untuk kelancaran pembiayaan. Dana pihak ketiga menjadi sangat urgen dalam aktivitas pengembangan ekonomi masyarakat dalam sektor riil. Tingkat kepercayaan masyarakat kepada bank syariah dapat dilihat dari peningkatan jumlah dana pihak ketiga yang 
dimiliki oleh bank syariah (Mira, 2018, pp. 6-7). Berikut ini data tentang keberadaan dana pihak ketiga pada perbankan syariah Indonesia.

Tabel 1. Dana Pihak Ketiga Perbankan Syariah

\begin{tabular}{cc}
\hline Tahun & Jumlah Danak Pihak Ketiga (Triliun Rupiah) \\
\hline 2015 & 236.020 \\
2016 & 285.200 \\
2017 & 341.700 \\
2018 & 379.960 \\
2019 & 425.290 \\
\hline
\end{tabular}

Sumber : www.ojk.go.id

Data tersebut diatas menunjukkan bahwa dana pihak ketiga pada perbankan syariah di Indonesia mengalami peningkatan, kondisi ini memperlihatkan bahwa masyarakat semakin menaruh kepercayaan terhadap keberadaan bank syariah. Namun pertumbuhan perbankan syariah belum dapat mengimbangi perbankan konvesional, padahal masyarakat Indonesia yang notabene adalah mayoritas berpenduduk muslim.

Faktor internal dan eksternal merupakan faktor yang mempengaruhi dana pihak ketiga. Faktor internal terdiri dari tingkat bagi hasil, kualitas layanan, jumlah kantor layanan, likuiditas dan lainnya. Sedangkan faktor eksternal atau faktor ekonomi diantaranya inflasi, tingkat suku bunga Bank Indonesia, equivalent rate, nilai kurs, produk domestik bruto (Nova, 2017, pp. 3-4).

Penelitian yang membahas tentang dana pihak ketiga sebenarnya sudah banyak dilakukan (Andriyanti \& Wasilah, 2010), ( (Annisa, Riduan, \& Amanah, 2013), (Hermanto, 2008), (Natalia, 2014), (Wulandari, 2014), (Siti, 2019), (Ummu, 2018), (Evi, 2018), (Nofinawati, 2018), (Almira \& Dina, 2017) (Yenti \& Romi, 2018), namun hasilnya masih berbeda-beda sehingga masih mempunyai ruang untuk melanjutkankan penelitian ini.

Pada penelitian dilakukan untuk periode 2015-2019 pada perbankan syariah dengan menggunakan variabel independen diantaranya equivalent rate, inflasi dan likuiditas. Sehingga tujuan dari peneliti ini yaitu untuk menganalisis pengaruh equivalent rate, inflasi dan likuiditas terhadap dana pihak ketiga pada perbankan syariah.

\section{KERANGKA TEORITIS DAN PENGEMBANGAN HIPOTESIS}

\section{Dana Pihak Ketiga}

Dana pihak ketiga yang berbentuk tabungan, simpanan giro dan deposito merupakan sumber pendanaan perbankan yang berasal dari masyarakat atau nasabah. Dana pihak ketiga ini merrupakan sumber pendanaan yang terbesar dari perbankan yang mencapai 80 hingga $90 \%$ (Irham, 2015, p. 50).

Ismail, (2010:43) dana pihak ketiga merupakan dana yang diperoleh/ dihimpun oleh pihak perbankan dari masyarakat atau nasabah baik bersifat individu maupun institusional. Perkembangan dana pihak ketiga merupakan salah satu indikator pertumbuhan dari bank, artinya semakin tinggi dana pihak ketiga yang dimiliki bank tersebut maka bank tersebut akan mempunyai kesempatan yang besar untuk menyalurkan pembiayaan kepada nasabah. 
Sesuai dengan tugas utama bank yang tertuang dalam UU No. 21 tahun 2008 yaitu menghimpun dan menyalurkan dana dengan menawarkan produk dan jasa kepada masyarakat. Kunci utama dari kegiatan operasional perbankan adalah aktivitas penghimpunan dana. Semakin besar dana yang terhimpun maka akan semakin besar juga penyaluran dana melalui berbagai jenis pembiayaan kepada masyarakat.

\section{Equivalent Rate}

Equivalent rate berperan seperti istilah bunga pada bank konvensional, yang artinya besarnya tingkat return yang akan diperoleh atas aktivitas investasi yang dilakukan. Equivalent rate dihitung pada setiap akhir bulan setelah penanaman investasi telah dijalankan. Dalam kondisi ini nasabah dapat melakukan perkiraan akan equivalent rate yang akan diterimanya dengan melihat tingkat equivalent rate pada bulan-bulan sebelumnya (Amir \& Rukmana, 2010, p. 36).

Equivalent rate merupakan jumlah return atau bagi hasil yang diperoleh nasabah dan biasanya dinyatakan dalam persentasi, sehingga memudahkan bagi masyarakat untuk mengetahui berapa besar keuntungan yang akan diperolehnya. Pergerakan equivalent rate sangat dipengaruhi oleh kondisi ekonomi, jika kondisi ekonomi stabil maka perjalanan usaha atas invstasi yang dilakukan akan stabil dan tidak berfluktuasi yang tinggi atau terlalu rendah (Muhammad \& Rahmad, 2019, p. 71).

\section{Inflasi}

Inflasi merupakan kecendrungan menaiknya harga-harga produk dan biasanya berlangsung secara terus menerus. Inflasi dikatakan juga sebagai kondisi persentase kenaikan harga barang dan jasa yang di konsumsi oleh rumah tangga secara umum dan terus menerus (Siti, 2019, p. 24).

Jadi inflasi merupakan sebuah indikasi yang menunjukkan kenaikan harga produk dan jasa yang dikonsumsi rumah tangga secara umum dan berlangsung terus menerus sehingga terjadi ketidak seimbangan antara permintaan dengan persediaan barang atau jasa tersebut.

\section{Likuiditas}

Likuiditas merupakan kemampuan dari pihak bank dalam mempersiapkan dananya untuk keperluan saat ini dan masa mendatang khususnya untuk pembayaran kewajiban jangka pendek (Sinta, 2005). Penilaian aspek likuiditas akan memberikan gambaran tentang kemampuan bank untuk mengendalikan likuiditasnya dalam memenuhi utang-utangnya jangka pendek sesuai dengan perjanjian serta pemenuhan kebutuhan yang lain yang berjangka waktu pendek.

Tingkat likuiditas suatu bank dapat diukur dengan FDR (Financial to Deposit Ratio) yaitu dengan membandingkan komposisi dana yang telah disalurkan pada kredit dengan dana pihak ketiga yang diperoleh. Semakin kecil tingkat likuiditas ini akan menjadi permasalahan bagi pihak bank yang menandakan bahwa pihak bank kewalahan dalam memenuhi kewajibannya untuk jangka waktu pendek. 


\section{Equivalent Rate dengan Dana Pihak Ketiga}

Equivalent rate merupakan imbal hasil yang diperoleh nasabah atas investasi dana yang dilakukan melalui pihak bank yang dihitung setiap akhir bulan. Setiap nasabah yang menginvestasi dananya dalam bentuk simpanan giro, tabungna dan deposito sudah tentu mempunyai ekspestasi terkait dengan keuntungan yang akan diperolehnya.

Dalam penelitiannya Nurisma \& Ditya (2020), Riska (2017) tingkat equivalent rate akan mempengaruhi nasabah untuk menginvestasikan dananya di bank syariah, semakin tinggi equivalent rate maka akan semakin besar keinginan masyarakat untuk menginvestasikan dananya.

Masyarakat Indonesia mayoritas muslim, dimana jika berinvestasi di bank konvesional tentu akan memperoleh bunga. Sementara berbicara dengan bunga dalam Islam, hukumnya adalah haram. Maka dalam hal ini keberadaan bank syariah diuntungkan dengan kondisi masyarakat Indonesia yang mayoritas muslim, dimana tentunya masyarakat akan lebih tertarik berinvestasi pada bank syariah karena terhindar dari yang namanya bunga.

Dari penjelasan tersebut, maka dapat diajukan hipotesis penelitian yaitu:

$\mathrm{H}_{1}$ : Terdapat pengaruh equivalent rate terhadap dana pihak ketiga pada perbankan syariah di Indonesia.

\section{Inflasi dengan Dana Pihak Ketiga}

Inflasi merupakan kondisi dimana terjadi kenaikan harga produk yang dibutuhkan masyarakat untuk keperluan sehari-hari secara umum dan berlangsung secara terus menerus. Inflasi berlangsung karena melonjaknya permintaan terhadap barang tersebut dipasar sehingga melebihi dari barang yang ditawarkan.

Dalam penelitiannya Rosiatul (2017, pp. 141-142) tingak inflasi tidak menjadi tolak ukur dalam penghimpulan dana pihak ketiga pada PT. BRI Syariah, hal ini terbukti dari hasil yang diperoleh bahwa inflasi tidak memberikan effek terhadap dana pihak ketiga. Secara umum inflasi akan memberikan pengaruh yang negatif terhadap perekonomian. Pada saat terjadi inflasi, biasanya masyarakat akan menarik tabungan guna untuk memperoleh barang, kondisi ini akan mengakibatkan terjadinya kekurangan dana pada pada bank tersbebut dan dapat berakibat fatal yaitu penutupan akan bank itu.

Dari penjelasan tersebut, dapat diajukan hipotesis dalam penelitian ini:

$\mathrm{H}_{2}$ : Terdapat pengaruh inflasi terhadap dana pihak ketiga pada perbankan syariah di Indonesia.

\section{Likuiditas dengan Dana Pihak Ketiga}

Likuiditas adalah keadaan yang menjelaskan bahwa kemampuan perusahaan dalam memenuhi kewajibannya dan kebutuhan lainnya dalam jangka waktu yang pendek dan tepat waktu. Bank yang likuid juga menggambarkan kemampuan perusahan dalam mengelola kegiatannya secara efektif, efisien sehingga dapat meminimalisasi biaya pengelolaan likuiditas yang tinggi.

Jika dilihat dari sisi assetnya, maka likuiditas tersebut adalah bank dalam mengubah assetnya menjadi uang tunai dalam waktu yang pendek, kemudian jika ditinjau dari segi 
utangnya likuiditas merupakan kemampuan dari bank syariah dalam memenuhi kebutuhan dana yang dilakukan dengan cara peningkatan portofolio likuiditas ( (Zaini, 2014, p. 287).

Salah satu pengukuran dari tingkat likuiditas adalag dengan Financial Deposit Ratio (FDR) yaitu dengan membandingkan komposisi dana pada kredit dengan dana pihak ketiga yang diperoleh oleh bank tersebut. Prihartiningsih (2012) Financial to deposit rasio adalah pembiayaan yang disalurkan oleh pihak bank dibandingkan dengan dana pihak ketiga yang berhasil dihimpun.

Dari penjelasan tersebut diatas, dapat diajukan hipotesis dalam penelitian ini yaitu:

$\mathrm{H}_{3}$ : Terdapat pengaruh likuiditas terhadap dana pihak ketiga pada perbankan syariah di Indonesia.

Berdasarkan teori dan kajian penelitian terdahulu yang telah dilakukan, maka dapat digambarkan kerangka berpikir dari penelitian ini, yaitu:

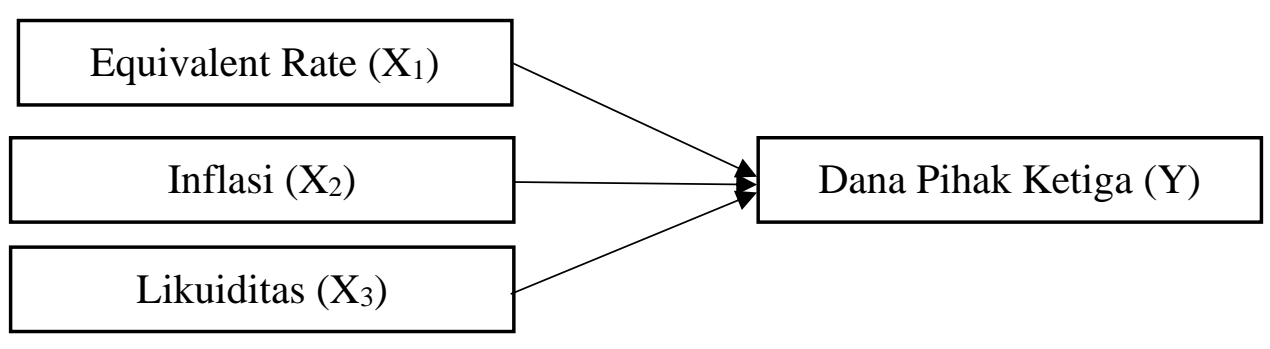

Gambar 1. Kerangka Penelitian Untuk Penelitian ini.

\section{METODE PENELITIAN}

Penelitian ini dilakukan pada perbankan syariah Indonesia yang datanya diperoleh melalui laman resmi dari OJK dan Bank Indonesia www.ojk.go.id dan www.bi.go.id. Jenis penelitian adalah asosiatif yaitu melihat pengaruh diantara variabel independen terhadap variabel dependen. Adapun variabel yang digunakan dalam penelitian ini adalah equivalent rate $\left(\mathrm{X}_{1}\right)$, inflasi $\left(\mathrm{X}_{2}\right)$, likuiditas $\left(\mathrm{X}_{3}\right)$ dan dana pihak ketiga $(\mathrm{Y})$.

Populasi dalam penelitian ini adalah laporan keuangan bulanan perbankan syariah yang dipublikasi oleh Otoritas Jasa Keuangan dan Bank Indonesia dari periode 2015 s.d 2019 yang berjumlah 60 bulan, data yang diperlukan dari laporan keuangan tersebut adalah equivalent rate, inflasi, likuiditas dan dana pihak ketiga.

Sampling jenuh adalah teknik sampling yang digunakan dalam penelitian ini. Maka besarnya sampel dalam penelitian ini adalah 60 bulan yaitu laporan keuangan bulanan dari tahun 2015-2019. Data diperoleh melalui studi kepustakaan dan dokumentasi. Analisis data yang dilakukan adalah analisis statistic deskriptif, uji asumsi klasik, uji hipotesis. 


\section{HASIL PENELITIAN DAN PEMBAHASAN}

\section{Hasil Penelitian}

\section{Analisis Statistik Deskriptif}

Berikut hasil uji statistik deskriptif:

Tabel 2. Hasil Uji Descriptive Statistics

\begin{tabular}{lrrrrr}
\hline & N & Minimum & Maximum & \multicolumn{1}{c}{ Mean } & Std. Deviation \\
\hline EQR & 60 & 3,86 & 6,57 & 4,9260 &, 67562 \\
Inflasi & 60 & 2,48 & 7,26 & 3,9898 & 1,37212 \\
Likuiditas & 60 & 2.03 & 4.38 & 1.5212 & 1.14612 \\
DPK & 60 & 240277,00 & 416478,00 & 300214,0340 & 64242,20757 \\
Valid N (listwise) & 60 & & & & \\
\hline er: Data diolah, SPSS & & & & &
\end{tabular}

Tabel diatas menunjukkan kondisi variabel equivalent rate dengan $\mathrm{N}$ sebanyak 60 pada peride 2015-2019 mempunyai nilai rata-rata 4,9260 dengan nilai standar deviasi 0,67562. Hal ini menunjukkan bahwa nilai mean berada diatas nilai standar deviasi yang dapat dimaknai variabel equivalent rate digolongkan baik dengan nilai minimum 3,86 dan maximum 6,57. Variabel infasi memperoleh nilai rata-rata 3,9898 dengan nilai standar deviasi 1,37212, hasil ini menunjukkan bahwa nilai mean berada diatas standar deviasi yang dapat dinyatakan bahwa variabel inflasi dikategorikan baik dengan nilai minimum 2,48 dan nilai maximum 7,26. Variabel likuiditas diperoleh nilai rata-rata sebesar 1,5212 dengan standar deviasi sebesar 1,14612 , hasil ini menunjukkan bahwa nilai mean dari variabel likuiditas berada diatas nilai standar deviasi yang dapat dikategorikan baik dengan nilai minimum 2,03 dan nilai maksimum4.38. variabel dana pihak ketiga diperoleh nilai rata-rata sebesar 300214,0340 dengan standar deviasi 64242,2075. Hasil ini menunjukkan bahwa nilai rata-rata berada diatas nilai standar deviasi yang dapat dikategorikan bahwa variabel dana pihak ketiga adalah baik dengan nilai minimum sebesar 240277,00 dan nilai maximum sebesar 416478,00.

\section{Uji Asumsi Klasik}

\section{Uji Normalitas}

Pengujian normalitas data dilakukan dengan uji Kolmogrof-Smirnov, pada taraf signifikan 0,05. Berikut hasil pengolahan data dengan bantuan aplikasi SPSS:

Tabel 3. Hasil Uji Normlitas One-Sample Kolmogorov-Smirnov Test

\begin{tabular}{llr}
\hline N & & $\begin{array}{c}\text { Unstandardized } \\
\text { Residual }\end{array}$ \\
\hline Normal Parametersa,b & Mean & 60 \\
& Std. Deviation & 39985,685900000 \\
Most Extreme Differences & Absolute &, 081 \\
& Positive &, 053 \\
Kolmogorov-Smirnov Z & Negative &,- 081 \\
Asymp. Sig. (2-tailed) & &, 625 \\
\hline Sumber: Data diolah SPSS & &, 830 \\
\hline
\end{tabular}


Tabel 3 diatas menunjukkan bahwa nilai asymp.sig. (2-tailed) sebesar 0,830, nilai ini lebih besar dari taraf signifikan yaitu 0.05 . Hasil ini dapat dikatakan bahwa data tentang variabel equivalent rate, inflasi, likuiditas dan dana pihak ketiga berdistribusi normal.

\section{Uji Multikolinearitas}

Hasil uji multikolinearitas dapat dilihat pada tabel 4.

Tabel 4. Uji Multikolinearitas

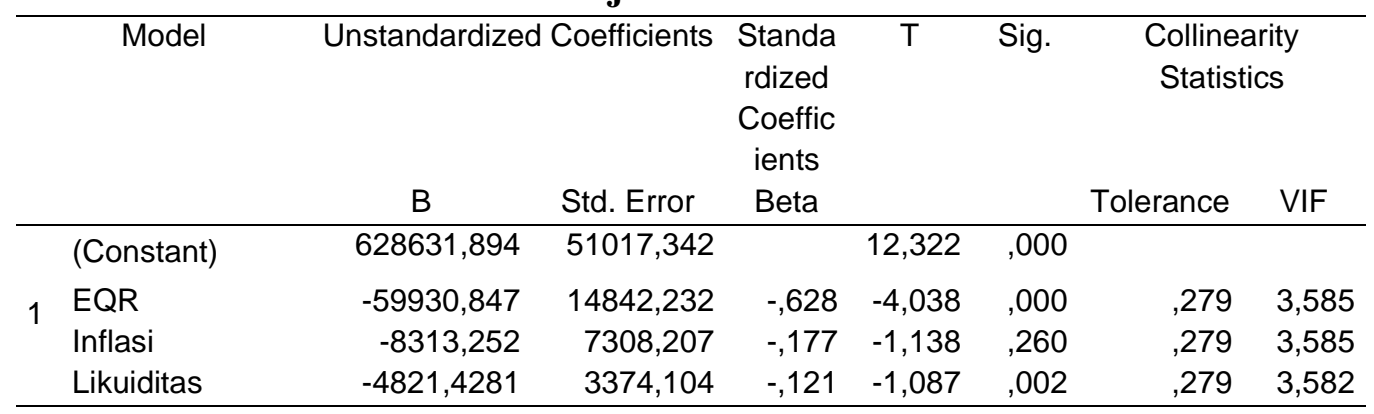

Sumber: Data diolah, SPSS

Ketentuan yang digunakan adalah dengan melihat nilai VIF, dari hasil pengolahan data diatas dapat dilihat bahwa nilai VIF dari equivalent rate, inflasi dan likuiditas lebih kecil dari ketentuan nilai VIF yaitu 5. Dapat disimpulkan bahwa ketiga variabel independen tidak terjadi multikolinearitas.

\section{Uji Heteroskedastisitas}

Dalam menguji terdapat atau tidaknya heterokedastisidas pada variabel penelitian ini digunakan uji Glejser.

Tabel 5. Uji Heteroskedastisitas

\begin{tabular}{|c|c|c|c|c|c|c|}
\hline & & & $\begin{array}{l}\text { Unstandardi } \\
\text { zed Residual }\end{array}$ & EQR & Inflasi & Likuiditas \\
\hline \multirow{14}{*}{$\begin{array}{l}\text { Spearman's } \\
\text { rho }\end{array}$} & Unstandardized & $\begin{array}{l}\text { Correlation } \\
\text { Coefficient }\end{array}$ & 1,000 &,- 103 &,- 201 &,- 159 \\
\hline & \multirow[t]{3}{*}{ Residual } & Sig. (2-tailed) & & ,433 &, 123 & .147 \\
\hline & & $\mathrm{N}$ & 60 & 60 & 60 & 60 \\
\hline & & Correlation &,- 103 & 1,000 &, $577^{* *}$ & $-264^{* *}$ \\
\hline & \multirow{4}{*}{ EQR } & Coefficient & & & & \\
\hline & & Sig. (2-tailed) & ,433 & & ,000 & .002 \\
\hline & & $\mathrm{N}$ & 60 & 60 & 60 & 60 \\
\hline & & Correlation &,- 201 &, $577^{\star \star}$ & 1,000 & .006 \\
\hline & \multirow{3}{*}{ Inflasi } & Coefficient & & & & \\
\hline & & Sig. (2-tailed) & ,123 & ,000 & & .847 \\
\hline & & $\mathrm{N}$ & 60 & 60 & 60 & 60 \\
\hline & \multirow[t]{3}{*}{ Likuiditas } & $\begin{array}{l}\text { Correlation } \\
\text { Coefficient }\end{array}$ &,- 159 & $-264^{* *}$ & .006 & 1,000 \\
\hline & & Sig. (2-tailed) & .147 & .002 & .847 & \\
\hline & & $\mathrm{N}$ & 60 & 60 & 60 & 60 \\
\hline
\end{tabular}

Sumber: Data diolah SPSS

Tabel diatas menunjukkan bahwa nilai sig EQR sebesar 0.433, inflasi sebesar 0,123 dan likuiditas 0.147 . Nilai signifikan dari ketiga variabel posisinya lebih besar dari tingkat signifikansi yang ditentukan yaitu $5 \%(0,05)$, maka dapat disimpulkan bahwa tidak terjadi heteroskedastisitas pada model regresi dalam penelitian ini. 


\section{Uji Autokorelasi}

Berikut ini hasil uji autokorelsi:

Tabel 6. Uji Autokorelasi

\begin{tabular}{|c|c|c|c|c|c|}
\hline Model & $\mathrm{R}$ & R Square & $\begin{array}{l}\text { Adjusted R } \\
\text { Square }\end{array}$ & $\begin{array}{l}\text { Std. Error of the } \\
\text { Estimate }\end{array}$ & Durbin-Watson \\
\hline 1 &, $784^{a}$ & ,615 & ,601 & 40681,14128 & , 147 \\
\hline
\end{tabular}

Tabel diatas memperlihatkan bahwa nilai Durbin-Watson diperoleh sebesar 0,147 dengan tingkat signifikansi 0.05 , dimana hasil ini berada pada $-2<\mathrm{DW}<+2$ sama dengan -2 $<0,147<+2$, maka dapat disimpulkan tidak terjadi autokorelasi.

\section{Uji Hipotesis}

Berdasarkan hasil pengolahan data dengan bantuan aplikasi SPSS diperoleh hasil:

\section{Tabel 7 Pengujian Hipotesis Penelitian}

\begin{tabular}{ccccc}
\hline Hipotesis & $\begin{array}{c}\text { Variabel } \\
\text { Penelitian }\end{array}$ & Koefisien & Nilai Sig. & Kesimpulan \\
& EQR & $-59930,847$ & 0,00 & Diterima \\
$\mathrm{H}_{1}$ & Inflasi & $-8313,252$ & 0,236 & Ditolak \\
$\mathrm{H}_{2}$ & Likuiditas & $-4821,4281$ & 0,02 & diterima \\
$\mathrm{H}_{3}$ & & & \\
\hline
\end{tabular}

Sumber : Data Diolah melalui SPSS

\section{PEMBAHASAN}

\section{Pengaruh Equivalent Rate Terhadap Dana Pihak Ketiga}

Hasil penelitian menunjukkan bahwa equivalent rate berpengaruh terhadap dana pihak ketiga pada perbankan syariah di Indonesia periode 2015-2019. Seiring dengan hasil yang ditemukan oleh Nurisma \& Ditya (2020) bahwa tingkat return yang diperoleh oleh nasabah dari suatu aktivitas penghimpunan dana dipengaruhi oleh equivalent rate dan dana pihak ketiga. Jadi imbalan yang akan diperoleh oleh nasabah dipengaruhi oleh equvalent rate. Penentuan equivalent rate akan sejalan dengan kondisi perekonomian secara makro. Kestabilan dari keadaan perekonomian di negara kita akan memberikan rangsangan kepada masyarakat dalam menggunakan dana yang dimilikinya.

Jika dilihat dari nilai koefisien dari hasil penelitian ini menunjukkan tanda negatif, artinya jika equivalent rate mengalami peningkatan maka akan menyebabkan penghimpunan dana pihak ketiga menurun. Kondisi ini sebenarnya disebabkan karena penentuan equivalent rate tersebut berfluktuasi sehingga memberikan pilihan kepada nasabah dalam menempatkan dananya apakah ditabung atau digunakan untuk konsumsi sehari-hari. Penelitian ini sejalan dengan hasil penelitian yang dilakukan oleh Zulfikar Syarif dan bertentangan dengan penelitian Vera Susanti.

\section{Pengaruh Inflasi Terhadap Dana Pihak Ketiga}

Hasil penelitian ini menunjukkan bahwa inflasi tidak berpengaruh terhadap dana pihak ketiga pada perbankan syariah di Indonesia periode 2015-2019. Inflasi merupakan terjadinya 
kenaikan harga kebutuhan rumah tangga secara terus menerus untuk periode tertentu. Umumnya jika terjadi inflasi maka keinginan masyarakat untuk menabung di bank akan menurun karena masyarakat lebih mementingkan konsumsi rumah tangganya.

Hasil penelitian ini bertanda negatif pada nilai koefisiennya, artinya jika inflasi mengalami kenaikan maka penghimpunan dana pihak ketiga akan mengalami penurunan. Kondisi ini disebabkan karena dengan terjadinya inflasi maka akan mengakibatkan melemahnya nilai uang akibat dari naiknya harga barang atau jasa. Tentu hal ini akan mengurangi minat masyarakat untuk menyimpan dananya dibank karena adanya perasaan takut akan susahnya untuk memperoleh barang dan jasa yang akan digunakan untuk keperluan sehari-hari, artinya masyarakat lebih mengutamakan penggunaan dananya untuk memperoleh barang dan jasa ketimbang menyimpannya dibank.

Namun dalam penelitian ini inflasi tidak berpengaruh terhadap dana pihak ketiga, keadaan ini menunjukkan bahwa umat Islam meyakini bahwa Perbankan Syariah merupakan salah satu solusi yang tepat mengatasi kegagalan sistem perbankan selama ini dalam menangani laju inflasi serta kemampuan pemerintah untuk mengatur moneter dalam negeri. Akibatnya meskipun terjadi inflasi yang tinggi, masyarakat tetap melakukan investasi keuangan atau akan tetap menabung melalui Perbankan Syariah.Penelitian ini sejalan dengan penelitian yang dilakukan oleh (Annisah \& Amanah, 2013), (Novianto \& Hadiwidjojo, 2013), Nurjannah, (Nofinawati, 2018).

\section{Pengaruh Likuiditas Terhadap Dana Pihak Ketiga}

Berdasarkan hasil pengujian terhadap data-data dalam penelitian ini ditemukan hasil bahwa likuiditas yang diukur dengan financial deposit ratio berpengaruh terhadap dana pihak ketiga pada perbankan syariah di Indonesia periode 2015-2019. Likuiditas adalah kemampuan dari pihak bank dalam mempersiapkan dananya untuk keperluan saat ini dan masa mendatang khususnya untuk pembayaran kewajiban jangka pendek (Sinta, 2005). Dalam penelitian ini likuiditas diukur dengan Financial Deposit Ratio yang artinya rasio yang melihat kemampuan bank dalam mengubah asset menjadi uang tunai jika dilihat dari sisi asset, kemudian jika dilihat dari utang berarti kemampuan bank dalam memenuhi kewajiban jangka pendek dengan peningkatan portofolio utangnya.

Dengan semakin baik tingkat likuiditas bank syariah, maka akan menambah kepercayaan masyarakat untuk menaruh dananya baik berupa tabungan maupun deposito sehingga akan menambah dana pihak ketiga dari bank syariah tersebut dan pada akhirnya semakin banyak peluang dalam aktivitas pembiayaan kepada nasabah yang membutuhkannya. Penelitian ini sejalan dengan (Zaini, 2014) dan bertentang dengan hasil penelitian dari (Annisa, Riduan, \& Amanah, 2013).

\section{KESIMPULAN, SARAN DAN KETERBATASAN}

Berdasarkan kajian teoritis maupun analisis data-data penelitian diperoleh kesimpulan: Equivalent rate dan Likuiditas yang diukur dengan Financial Deposit Ratio berpengaruh terhadap dana pihak ketiga pada perbankan syariah di Indonesia periode 2015-201. Sedangkan Inflasi tidak berpengaruh terhadap dana pihak ketiga pada perbankan syariah di Indonesia periode 2015-2019 
Penelitian hanya dilakukan pada perusahaan perbankan syariah selama periode 20152019, untuk penelitian selanjutnya dapat memperluas baik dari sisi objek penelitiannya maupun periodesiasi. Kemudian penelitian berikutnya dapat menambah variabel independen diantaranya kurs rupiah, valuta asing atau menggunakan pengukuran yang lain dari likuiditas.

\section{DAFTAR PUSTAKA}

Almira, U. N., \& Dina, F. S. (2017, November). Pengaruh Equivalent Rate, Profitabilitas dan Jumlah Kantor Terhadap DPK BPRS. Jurnal Ekonomi Syariah Teori dan Terapan, 4(11).

Amir, M., \& Rukmana. (2010). Bank Syariah. Jakarta : Erlangga.

Andriyanti, \& Wasilah. (2010). Faktor Yang Mempengaruhi Jumlah Penghimpunan Dana Pihak Ketiga . SNA XIII.

Annisa, N., Riduan, A., \& Amanah. (2013). Faktor-Faktor Yang Mempengaruhi Pertumbuhan Deposito mudharabah Bank Syariah. Jurnal Ilmu Riset dan Riset Akuntansi.

Annisah, N. R., \& Amanah. (2013). Faktor-faktor Yang Mempengaruhi Pertumbuhan Deposito Mudharabah. Jurnal Ilmu dan Riset Akuntansi, 1(2).

Belinda, F. I. (2017). Pengaruh Bagi Hasil, Inflasi dan Kurs Dollar Terhadap DPK di BMI Tahun 2011-2015. Skripsi UIN Raden Patah Palembang.

Evi, R. (2018). Pengaruh Inflasi, Suku Bunga Terhadap DPK Perbankan Syariah. Skripsi UIN Sultan Maulana Hasanuddin Banten.

Hermanto. (2008). Faktor-Faktor Yang Mempengaruhi Dana Pihak BUS 2005-2007. Skripsi UIN Sunan Kalijaga.

Irham, F. (2015). Manajemen Perbankan Konvensional dan Syariah. Jakarta: Mitra Wacana Media.

Ismail. (2010). Manajemen Perbankan dari Teori Menuju Aplikasi. Jakarta: Kencana.

Mira, A. (2018). Analisis Fakto Internal dan Eksternal Terhadap Volume Dana Pihak Ketiga Pada Bank Umum Syariah. Skripsi UIN Sunan Kalijaga Yogyakarta.

Muhammad, I. H., \& Rahmad, D. H. (2019). Analisis Faktor-Faktor Yang Mempengaruhi Asset BPRS. At-Tijaroh: Jurnal Ilmu Manajemen dan Bisnis Islam, 5(1).

Natalia, E. (2014). Pengaruh Tingkat Bagi Hasil Deposito Bank Syariah dan Suku Bunga Deposito Bank Umum Terhadap Jumlah Simpanan Deposito Mudharabah. Jurnal Administrasi Bisnis (JAB).

Nofinawati. (2018, Desember). Pengaruh Inflasi, BI Rate, dan Nilai Tukar Rupiah Tehadap DPK pada Perbankan Syariah di Indonesia. Jurnal IMARA, 2(2).

Nova, F. K. (2017). Analisis Faktor yang Mempengaruhi DPK Pada Bank Umum Syariah di Indonesia. Skripsi UPI.

Novianto, \& Hadiwidjojo. (2013). Analisis Faktor Yang Mempengaruhi Penghimpunan Deposito Mudharabah Perbankan Syariah di Indonesia.

Nurisma, F. Z., \& Ditya, P. (2020). Pengaruh Suku Bunga, BI Rate an Jumlah Kantor Terhadap Penghimpunan DPK pada BUS. Jurnal Penelitian Ekonomi dan Akuntansi, 5(2).

Pandji, A. (2009). Manajemen Bisnis. Jakarta: Rineka Cipta. 
Prihartiningsih. (2012). Dinamika Financing To Deposit Rasio Perbankan Syariah. Prodi AKuntansi Politeknik Negeri Semarang, 8(3).

Riska, R. M. (2017). Pengaruh Profitabilitas, Ukuran Perusahaan dan Equivalent Rate Terhadap DPK pada Bank Syariah. Skripsi FEB, Airlangga, Surabaya.

Rosiatul, L. (2017). Pengaruh Inflasi, Nilai Tukar Rupiah, BI Rate dan Jumlah Uang Beredar Terhadap DPK PT. BRI Syariah. Skripsi, IAIN Tulung Agung.

Salusu. (2015). Pengambilan Keputusan Strategik Untuk Organisasi publik dan Organisasi Non Profit. Jakarta: PT. Grasindo.

Sinta, S. (2005). Penggunaan Rasio Keuangan Dalam Memprediksi Laba Pada Masa Yang Akan Datang. Jurnal Akuntansi dan Manajemen, XVI(3).

Siti, C. Z. (2019). Pengaruh Equivalent Rate, Bagi Hasil, Profitabilitas dan Jumlah Kantor Terhadap DPK pada BPR Syariah. Skripsi UINSU Medan.

Ujung, S. (2015). Perilaku Konsumen Teori dan Penerapannya dalam Pemasaran. Bogor: Ghalia Indonesia.

Ummu, R. (2018). Pengaruh Tingkat Keuntungan, Equivalent Rate, Jumlah Kantor, dan Inflasi Terhadap DPK pada Perbankan Syariah. Skripsi IAIN Surakarta.

Wulandari, S. (2014). Analisis Faktor Internal dan Eksternal Yang Mempengaruhi DPK Bank Umum Syariah di Indonesia.

Yenti, A., \& Romi, I. (2018, Juli-Desember ). Pengaruh Inflasi, Kurs, Tingkat Suku Bunga, Pertumbuhan Ekonomi dan Jumlah Uang Beredar terhadap Jumlah DPK. Jurnal Kajian Ekonomi Islam, 3(2).

Zaini, Z. (2014). Memahami Bisnis Bank Syariah. Jakarta: PT. Gramedia Pustaka Utama. 